\title{
Legal Status of the Holding Company of Mining State-Owned Enterprises Under the Context of Direct Capital Participation Sourcing from the Separate State's Assets
}

\author{
Raden Roro Theresia Tri Widorini \\ Doctor Program Faculty Of Law \\ University Brawijaya \\ Malang, Indonesia \\ widorini7@gmail.com
}

\begin{abstract}
Establishment of Holding BUMN Mining was formally established on 27 November 2017 in Jakarta with PT. Indonesia Asahan Aluminum (Inalum) becomes the holding company of state-owned mining company PT Aneka Tambang Tbk, PT. Bukit Asam, Tbk, and PT. Timah, Tbk becomes a subsidiary. With this Holding BUMN Mining, the status of PT Aneka Tambang Tbk, PT. Bukit Asam, Tbk, and PT. Timah, Tbk changed from state-owned company to non-corporate status by marking the deed of transfer of shares of series $B$ by SOE Minister Rini Soemarno consisting of PT Aneka Tambang Tbk of $65 \%$, PT. Bukit Asam, Tbk at $65.02 \%$, PT. Timah, Tbk at $65 \%$ and PT. Freeport Indonesia of $9.36 \%$ owned by the Government into PT. Inalum (Persero) which is $100 \%$ owned by the state while still holding shares of series $A$ or dwiwarna in a subsidairy. With the change of status, based on Article 1 Sub-Article 1 of Law Number 19 Year 2003 concerning of SOEs, those who are categorized as SOEs are only holding companies, in the presence of the phrase "equity participation directly from wealth separated state "provides the consequences for the subsidiary of the parent company to be excluded from the category of SOEs so that there is a need to regulate the extent to which the flow of capital participation directly from the state flows to the subsidiary. Given the functions of SOEs as well as agent of development within the framework of implementing government policies aimed at the greatest extent to the prosperity of the people according to what has been mandated in Article 33 of the 1945 Constitution.
\end{abstract}

Keywords- Legal Status, Holding Company of Mining State-Owned Enterprises, Separate State's Assets

\section{INT RODUCTION}

Holding Company represents a vast parent organisation taking form of corporation which has a major control over stocks held by several business entities, accordingly, upon those shareholdings the holding company holds a control and may manage its controlled companies, in this case PT. Indonesia Asahan Aluminium (Inalum), having status as Limited Liability Company (pursuant to the Government Regulation Number 26 of 2014), which has been appointed as the holding company of State-Owned Mining Enterprises, namely PT Aneka Tambang (Antam) Tbk., PT. Bukit Asam, Tbk., and PT. Timah, Tbk., which in turn, becoming Inalum's subsidiaries by virtue of the Regulation of the
Government of the Republic of Indonesia Number 47 of 2017, dated 10th November 2017. The establishment of this Holding Company of Mining State-Owned Enterprises had consequently changed the corporate status of PT. Aneka Tambang Tbk., PT. Bukit Asam, Tbk., and PT. Timah, Tbk., into Limited Liabilities fully organised and operating under the Law Number 40 of 2007 on the Limited Liability Company (Article 4 letter a of the Government Regulation No. 47 of 2017) upon the execution of the deed of Class A Shares Transfer by the Minister of SOE, Rini Soemarno, the composition of transferred stocks of which was PT. Aneka Tambang (Antam) Tbk. for 65\%, PT. Bukit Asam, Tbk. for $65.02 \%$, PT. Timah, Tbk. for $65 \%$ and at the same occasion, the Minister of SOE, Rini Soemarno, also executed the shares trans fer of $9.36 \%$ PT. Freeport Indonesia's shares held by the Government into PT. Inalu m (Persero) of which $100 \%$ of its shares are held by the Indonesia's Government. This shares transfer is for the purpose of state's direct investment into the company's capital.

Nevertheless according to the Article 3 of the Government Regulation of the Republic of Indonesia Number 47 of 2017 dated 10th November 2017, State won't lose its control over PT Aneka Tambang (Antam) Tbk., PT. Bukit Asam, Tbk., and PT. Timah, Tbk due to the transfer of shares held by those three into PT. Indonesia Asahan Aluminium (Inalum), as State still has interests over bicolour Class A shares with more voting rights in those three companies as set forth in the Articles of Association. With the change of legal status of PT Aneka Tambang (Antam) Tbk., PT. Bukit Asam, Tbk., and PT. Timah, Tbk., above mentioned, how to bring with the accountability of allocation of the direct investments which are sourced from the State's assets separated from State Budged to be allocated as the SOE capital, in this case PT. Indonesia Asahan Aluminium (Inalum), into PT Aneka Tambang (Antam) Tbk., PT. Bukit Asam, Tbk., and PT. Timah, Tbk., bearing in mind that SOE serves also as the agent of development within the implementation frame of government policies intended for the greatest benefit of the people as set forth by the Article 33 of 1945 Constitution. 


\section{DISCUSSION}

A. State's controlover PT. Aneka Tambang (Antam)Tbk, PT. Bukit Asam, Tbk, dan PT. Timah, Tbk., is reflected by the ownership of bi-colour Class A shares with voting rights as set out in the Articles of Association

Mineral ownership based on the mandate of the constitution of article 33 of the 1945 Constitution, is in the hands of the Indonesian people mentioned that the earth, water and natural resources contained there in are controlled by the state and used for the greatest prosperity of the people. It is also mentioned in article 1 of Law no. 11 of 1967 that all the minerals contained in the territory of Indonesian mining law which are natural sediments as a gift of God Almighty are the national treasures of the Indonesian nation and are therefore controlled and used by the state for the greatest prosperity of the people[1]. In this case, as State has $100 \%$ interests over PT. Inalum and holds bi-colour Class A shares in PT Aneka Tambang (Antam) Tbk., PT. Bukit Asam, Tbk., and PT. Timah, Tbk, State remains possessing a control over the subsidiaries of SOEs and those subsidiaries are accountable to the State as the capital owner.

The Minister of State-Owned Enterprises is delegated with the position, duties and authorities to represent the Government as the Shareholder or within the General Meeting of Shareholders in order to appoint someone to sit in the Board of Directors and Board of Commissioners of the Subsidiaries (article 14 of the Copy of Regulation of the Minister of State-Owned Enterprises Number: PER - 03 / MBU / 2012 dated 29th March 2012). The Minister of Finance and Minister of State-Owned Enterprises hold a control over the SOEs' subsidiaries, both for the purpose of appointing the Board of Directors and Board of Commissioners, above mentioned, meanwhile, the Minister of Finance has duties and authorities to conduct the admin is trative function for the adminis trative activities of the state investment in the SOEs and Limited Liability Companies (Article 1 number 8 of the Government Regulation of the Republic of Indonesia Number 72 of 2016 dated 30th December 2016 on the Amendement to the Government Regulation Number 44 of 2005 dated 25th October 2005) ${ }^{1}$.

The Minister of Finance, in term of implementation of its authorities and fiscal management to the SOE's subsidiaries, namely PT Aneka Tambang (Antam) Tbk., PT. Bukit Asam, Tbk., and PT. Timah, Tbk, of which has undergone change in their legal status into Limited Liability Companies, may still perform its admin is trative functions, including series of admin istrative activities of state's direct investment either in the SOE or Limited Liability Companies, in view of that such investment under shares participation in PT Aneka Tambang (Antam) Tbk., PT. Bukit Asam, Tbk., and PT. Timah, Tbk, contained on another SOE, namely PT. Indonesia Asahan Aluminium (Inalum) (Persero), hence, as

The elucidation of the Article 26 of the Government Regulation of the Republic of Indonesia Number 72 of 2016 dated 30th December 2016 on the Amendment to the Government Regulation Number 44 of 2005 , dated 25th October 2005 stating that the Minister of Finance, in performing the administrative function, may leverage the participation value according to the specified documents, such as Government Regulation or Decision of the Minster of Finance (should the amount of participation value is delegated to the Minister of Finance) and Resolution of GMS or as specified by the Minister concerning the state's capital participation and any other documents. state's interests are mostly held by another SOE which has transformed into shares/ state capital in such SOE and become SOE assets recognised as a long-term investment in accordance with the percentage of Government's shareholding in such SOE, in which $100 \%$ shareholding in PT. Indonesia Asahan Aluminium (Inalu m) (Persero), in this area, the Government, as represented by the Minister of Finance will step in to provide development and supervision to the SOEs in order to conduct the administrative activities for any state capital participation or investment along with its allocation change in the SOEs, in which it is currently holding $50 \%$ interests in the ex-SOE subsidiaries and to the Limited Liability Company, as well (Article 3 letter a of the Government Regulation Number 41of 2003).

B. The Accountability of PT. Indonesia Asahan Aluminium (Inalum) as the Holding Company towards the State's capital participation in the subsidiaries, which is sourced from the state's assets separated from the State's Budget.

The Article 2A of the Government Regulation of the Republic of Indonesia Number 72 of 2016 on the Amendment to the Government Regulation Number 44 of 2005, stating that :

(1) The state's capital participation sourced from state's assets in the form of state-owned shares in SOEs or Limited Liability Companies as referred to in Article 2 clause (2) letter $d$ to the other SOEs or Limited Liability Companies shall be conducted by the Central Government without going through the mechanism of State Budget.

(2) In case of the state's ass ets in the form of state-owned shares in SOEs as referred to in Article 2 caluse (2) letter $d$ are used as state equity participation in other SOEs, hence, such shares are mostly owned by other SOEs, then such SOEs become subsidiaries of StateOwned Enterprises, provided that the state must hold shares the privileges as set forth in the articles of as sociation.

Article 2A clause (1) of the Government Regulation of the Republic of Indonesia Number 72 of 2016 dated 30th December 2016 on the Amendment to the Government Regulation Number 44 of 2005 dated 25th October 2005 mentioned above exposes a conflict of norms to the article 4 of Government Regulation Number 44 of 2005, in which: any participation/ investment of and increase in the state's capital of which funds are sourced from the State Budget, mus be carried out pursuant to the provisions of prevailing laws and regulation within the scope of state's financial affairs. The establishment of Government Regulation of the Republic of Indonesia Number 72 of 2016 is based on the Law No. 17 of 2003 on the State's Finance while the amendment thereof is based on the Government Regulation Number 44 of 2005, thence, there shall be no conflict arising.

Any separated assest in the state-owned enteripese/ regional-owned enterprises are included in the scope of state finances (Article 2 letter g) and the President as Head of Government holds the authority for the state financial management as part of the governmental authorities as set forth in Article 6 clause (1) and the President shall submit the draft Bill on the accountability of the implementation of the State Budget to the House of Representatives in the form of 
financial statements which has previously been audited by the State Audit Board. In the event of violation by the Minister / Chairman of the institution / Governor / Regent / Mayor to the policies as set forth in the Law on the State Budget / Regional Regulation on the Regional Budget, they shall be imprisoned and fined pursuant to the provisions of prevailing Laws (Article 34).

In this case, PT. Indonesia Asahan Aluminum (Inalum), as the holding company of State-s Owned Mining Enterprises, has been legally granted with new legas status as the Company by virtue of the Government Regulation Number 26 of 2014, and therefore, shall also be authorised to receive equity participation from separated state assets (Article 4 of Law of the Republic of Indonesia No. 19 of 2003 dated 19th June 2003). But in the case of the management of the source of funds, the subsidiary is responsible for the parent company because the fund used are not direct capital participation but the funds that has been processed and managed by the SOEs, so that if a subdiary suffers a loss, it will not affect the state losses. Losses in subsidiaries that will not affect the losses of the state will have an impact on losses to the holding company of SOEs although it has involved state equity participation from the separation of the State's wealth from the State Budget, even though it has transformed into shares / capital of SOEs to become a wealth of SOEs but the State will experience losses because if viewed from the source theory, that state money separated from the state budget to be invested in SOEs derived from public money so that management must be subject to state finances. That is why Law no. 19 of 2003 still places the control over the governance of the use of state funds under the authority of Indonesia's Audit Board, which in the post amendment to constitution, is placed as the highest auditive institution to oversee all uses of such funds by the country wherever the state money is allocated[2]. Therefore, in the articles of association that contain state finances within a period of one year, it requires proper management based on the applicable laws and regulations [3].

Theory of Transformation of state funds that turns into private money of the State-Owned Company with its status as a Company can actually drag too far paradigm management of SOEs regardless of the basic principles of Article 33 of the 1945 Constitution which underlies the welfare as the state's foundation in managing the state's economy. This is clarified in the elucidation of Law no. 17 of 2003 point 3 as follows : The approach used in formulating the State Finance is in terms of objects, subjects, processes, and objectives. From the process aspect, state finance includes all series of activities related to the management of objects as mentioned above, starting from policy formulation and decision making, up to its accountability in accordance with their duties and authorities. As linked up to the elucidation of Law no. 31 of 1999, the state finance in question is all state assets in any form, either separable or unseparable, including all parts of the state assets and any rights and obligations arising as it falls :

a) Under the control, ad min istration, and accountability of the state institutions officials, either at national or regional level ;

b) Under the control, ad min istration, and accountability of the State-Owned Enterprises / Regional - Owned Enterprises, foundations, legal entities, and companies receiving the state's direct capital participation, or any companies receiving third-party capital participation based on the agreement with the State.

The source of state assets derived from the Tate Budget indicates that the state's funds should be accountable to the people, the SOEs only acts as the bodies which manage such money while its nature of state's assets sourced from the State Budget still retains its characteristic as the state funds in accordance with Article 71 clause (2) of the Law No. 19 of 2003 stating that the Indonesian Audit Board has the authority to conduct an audit towards SOEs in accordance with the provisions of prevailing laws and regulations ${ }^{2}$.

As reviewed from HAN's theory on the institutional pers pective, the actions taken by SOEs can be categorized as part of the government's actions in the broad sense as well as the legal system in Indonesia, the purpose and objective of the establishment of SOEs as regulated in Article 2 clause (1) letter a of the Law Number 19 of 2003 rre to contribute to the development of the national economy in general and the state revenue in particular and article 2 clause (1) letter c states that the purpose and objective of the establishment of SOEs are also to carry out the public advantage of providing high quality and adequate goods and / or services for the fulfillment purpose of the public livelihood[2]. Historical Approach to the enactment of Law No. 17 of 2003 as the state finance that express the desire of the people to lay the foundation of professionalism, accountability, and transparency in the financial management so as not to result in the state losses.

Thus, state equity participation from the separated state's ass ets sourced from the State Budget is taking form of state's shares in the SOEs and Limited Liability Company, and it must be implemented in accordance with the provisions of prevailing laws and regulation within the state's financial sector in order to avoid any attempts that result in state's losses without any accountability and this is in line with the legal force of the Laws and Regulations under the hierarchy as referred to in clause (1). ${ }^{3}$ Like the Hans Kelsen Theory, any legal rule is the composition of the rules (stufenbau), meanwhile, the highest rules are grundnorm or fundamental

Article 6 of Law of the Republic of Indonesia Number 15 of 2006 on the Audit Board of the Republic of Indonesia, inc which:

(1) Indonesia's Audit Board is responsible for the management and state's financial accountability performed by the Central Government, Regional Government, other State Instit ut ionm Bank Indonesia, State-Owned Enterprises, Public Service Agency, Regional-Owned Enterprises, and other Institutions and agencies dealing with state's financial affairs.

(2) The implementation of audit by Indonesia's Audit Board as referred to in clause (1) shall be performed under the laws which regulate the audit to the management and accountability of state's financial affairs.

(3) The audit performed by Indonesia's Audit Board includes the audit to the financial matters, performance, and any other objectives.

Law of the Republic of Indonesia Number 15 of 2006 on the Audit Board of the Republic of Indonesia dated $30^{\text {th }}$ October 2006

Article 7 clause (1) of Law of the Republic of Indonesia No. 12 of 2011 dated $12^{\text {th }}$ August 2011, namely:

a. 1945 Constitution of the Republic of Indonesia

b. Order of the People's Constitutive Assembly

c. Law/ Government Regulation in lieu of Law

d. Government Regulation

e. President Regulation

f. Regional Regulation at Provicial Level

g. Regional Regulation at Regency/City Level.

Law of the Republic of Indonesia No. 12 of 2011, Bandung : Fokus Media, January 2018 
rules or fundamental rules that are the result of juridical thinking. A rule is a system of hierarchical legal rules. So that the validity of the lower legal rules shall be determined by the highest legal rules [4].

With the Government, in this case the Minister of Finance, takes an active role in term of development and supervision of the SOEs for the purpose of administration in any state's equity participation from the state's assets sourced from the State Budget, along with its amendment and from the stage of policy formulation, decision making, until its accountability to the SOEs having more than $50 \%$ interests in the subsidiaries of ex-SOE and to the subsidiaries with a Limited Liability Company status, accordingly, an Accounting Standard upon the management of state's direct investment to the SOEs is highly required and it also applies to the subsidiaries of which more than $50 \%$ of its shares are held by the SOE and the states as its ownership to bi-colour Class A shares in the subsidiaries of SOE, namely PT Aneka Tambang (Antam)Tbk, PT. Bukit Asam, Tbk, dan PT. Timah, Tbk. Bearing in mind the SOEs also function as the agent of development for the purpose of implementing the government policies which are intended for the greatest welfare of the people as set forth the Article $23 \mathrm{C}$ and Article 33 clause (3) of 1945 Constitution ${ }^{4}$.

\section{REFERENCES}

[1] T. Hayati, New Era of Mining Law, Under The Regime of Law No. UU No. 4 Year 2009. Jakarta: Yayasan Pustaka Obor Indonesia, 2015 .

[2] W. R. Tjandra, Hukum Keuangan Negara. Jakarta: PT. Gramedia, 2014.

[3] M. D. Saidi and E. M. Djafar, Hukum Keuangan Negara, 3rd ed. Jakarta: Rajawali Pers, 2008.

[4] Amiruddin and Z. Asikin, Pengantar Metode Penelitian Hukum. Jakarta: PT. RajaGrafindo Persada, 2004.

4 Article 23C of the 1945 Constitution, Miscelaneous provison concerning state finances which shall be regulated by Law and Article 33 clause (3): The earth and water and natural resources contained therein shall be controlled by the state and used for the great est welfare of the people.

1945 Constitution, Indonesia 